\title{
2015 Bunsen-Kirchhoff Award for Analytical Spectroscopy
}

\author{
DAAS Deutscher Arbeitskreis für Analytische Spektroskopie
}

\author{
Detlef Günther
}

Published online: 26 September 2014

(C) Springer-Verlag Berlin Heidelberg 2014

The DAAS -German Working group for Analytical Spectroscopy - regularly awards the "Bunsen-Kirchhoff-Preis für analytische Spektroskopie" to honour preferably the work of young scientists from universities, research institutes or industry who made excellent contributions to analytical spectroscopy. Especially preferred is an oeuvre in new areas like spectroscopy in nano compartments, spectroscopy of biomolecules, etc. The Award consists of an award-document and an amount of 2,500.00 $€$ sponsored by Perkin Elmer and the DAAS seeks nominations for the 2015 Bunsen-Kirchhoff Award for Analytical Spectroscopy. The Award will be presented at the ANAKON in March 2015 in Graz (Austria).

A nomination (in electronic form) should include:

1. Letter with the candidate's accomplishments

2. List of publications or recent work
3. Scientific curriculum vitae stating the age of the candidate; the candidate's address, phone, fax and e-mail.

Nominations can be made by members of DAAS but eligibility is open for any scientist meeting the requirements. Self-nomination is excluded. The decision as to whom the prize is to be awarded shall be made by a jury consisting of the current members of the board of DAAS.

Further information is available at: https://www.gdch.de/ netzwerk-strukturen/fachstrukturen/analytische-chemie/ arbeitskreise/ak-daas.html.

All documents should be sent not later than 20th December 2014 to:

Prof. Dr. Detlef Günther, President of the Jury for the Bunsen-Kirchhoff Award 2015, ETH Zürich, Laboratorium für Anorganische Chemie, Vladimir-Prelog-Weg 1, HCI G113, 8093 Zürich (Schweiz); e-mail: Secretary, Ms Nicole Bachmann (nbachmann@inorg.chem.ethz.ch).
D. Günther $(\bowtie)$

ETH Zürich, Laboratorium für Anorganische Chemie, Vladimir-Prelog-Weg 1, HCI G113, 8093 Zürich, Switzerland

e-mail: guenther@inorg.chem.ethz.ch 